\title{
Avasimibe and Sirt 1 Activators Reverse NAFLD and Obesity
}

\author{
Ian James Martins ${ }^{1,2,3 *}$ \\ ${ }^{1}$ Centre of Excellence in Alzheimer's disease Research and Care, School of Medical Sciences, Edith Cowan University, Australia \\ ${ }^{2}$ School of Psychiatry and Clinical Neurosciences, The University of Western Australia, Australia \\ ${ }^{3}$ Holywood Medical Centre, McCusker Alzheimer's Research Foundation, Australia
}

Submission: April 04, 2017; Published: June 02, 2017

*Corresponding author: Ian J Martins, School of Medical Sciences, Centre of Excellence in Alzheimer's disease Research and Care, School of Medical Sciences Edith Cowan University, 270 Joondalup Drive, Joondalup, Western Australia 6027, Australia, Tel: +61863042574 ;

Email: i.martins@ecu.edu.au

Keywords: Avasimibe; Sirtuin 1; Activator; Anti-aging; NAFLD; Obesity, Acyl-coenzyme A: cholesterol acyltransferase; Adipose tissue; Brain; Diet

\section{Opinion}

In epidemiological studies human obesity is clearly associated with the increased risk for atherosclerosis contributing to the early onset of coronary artery disease and diabetes. Visceral obesity in particular increases the risk of atherosclerosis owing to both insulin resistance and dyslipoproteinemia. Risk factors for atherosclerosis that could be exacerbated by obesity include hypertension and hyper lipidemia particularly hyper triglyceridemia which are risk factors for Alzheimer's disease. The susceptibility of humans to obesity is far higher compared with other species and in man favours the deposition of fat [1]. Amongst mammals humans have been reported to have the highest level of fatness than any other species and genes and environmental factors predispose humans to obesity [2]. Novel research provides information for antiaging genes with connections between appetite dysregulation, circadian desynchrony and non alcoholic fatty liver disease (NAFLD) in obesity [3]. Sirtuins are NAD+dependent protein deacetylasesthat target transcription factors to adapt gene expression to metabolic activity. Sirtuin 1 (Sirt1) is linked to life span, obesity and cardiovascular disease with effects on liver steatosis, inflammation, food intake, energy metabolism, cognition, mitochondrial biogenesis, neurogenesis, glucose/ cholesterol metabolism and amyloidosis [3,4]. Regulation by calorie restriction of Sirt1 in extending life span has been recognized with novel dietary activators of Sirt1required [3] that have therapeutic potential for reversal of high fat induced metabolic damage with the prevention of NAFLD $[5,6]$.

The understanding of molecular mechanisms that predispose individuals to obesity may involve high fat diets involved in Sirt 1 repression linked to the defective adipose tissue-liver crosstalk [7-9]. Molecular mechanisms involving diet and drugs that target and reduce the size of the adipose tissue and the development of obesity have become of interest to the biomedical community. The enzyme acyl-coenzyme A: cholesterol acyltransferase 1 (ACAT1) esterifies cholesterol with long-chain fatty acids, and thereby controls the absorption of cholesterol and dietary fat from the intestine [10] that plays an important role in hepatic apo B (cholesterol lipoproteins) and amyloid beta generation [11-14]. The use of ACAT inhibitors such as Avasimibe [15,16] reduce intestinal fatand regulate adipose tissue size to maintain liver ACAT activity and hepatic apo B metabolism [11].

In high fat studies in mice after 6 week mice developed liver steatosis with neuro degeneration [16]. The ACAT inhibitor Avasimibe in mice reduced intestinal fat absorption and reversed fatty liver and neuro inflammation with marked improvement in growth when compared with mice not consuming Avasimibe. An ACAT inhibitor such as Avasimibe (Figure 1) may provide better therapy to maintain the hepatic and brain Sirt1 activity and halt and delay the onset of liver and brain oxidative stress in obesity and other chronic diseases [3]. Avasimibe can be considered as an anti-aging drug that targets the periphery (adipose tissueliver crosstalk) $[7,8]$ and the brain with relevance to its use with other synthetic Sirt 1activating compounds [17] that require evaluation and assessment in rodent, primate and human trials.

\section{Conclusion}

Healthy diets and its therapeutic use in obesity and diabetes may be ineffective with relevance to drug induced mitophagy [18]. Avasimibe and its use with other Sirt 1 activators have become of importance to drug therapy in obesity and diabetes with relevance to the acceleration of hepatic drug metabolism with the prevention of mitochondrial apoptosis [18]. The use 
of synthetic Sirt 1 activators with healthy diets may prevent brain disease (Figure 1) and NAFLD that are associated with the induction of global obesity linked diabetes [19].

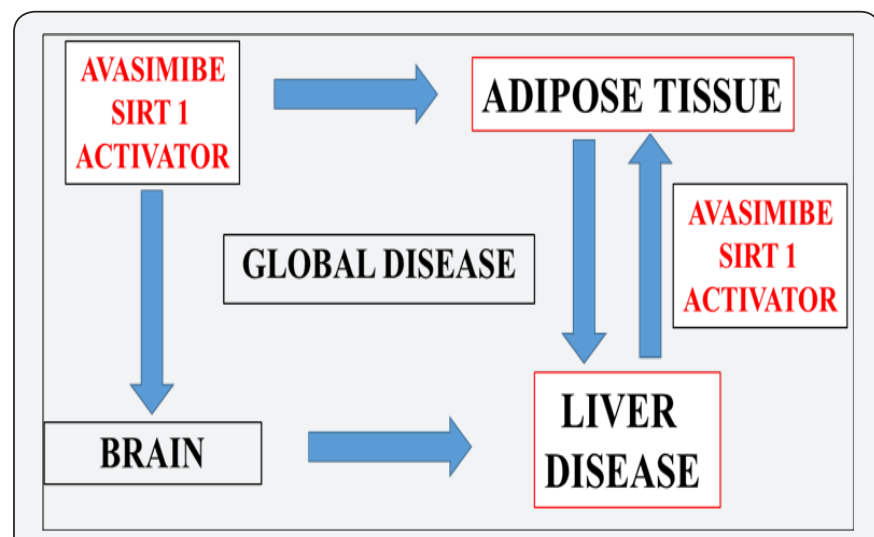

Figure 1: Avasimibe (ACAT inhibitor) reduces intestinal fat with effects on the adipose-tissue crosstalk. Avasimibe reverses NAFLD and prevents neuro degeneration. Avasimibe by reducing intestinal fat modulates the calorie sensitive gene Sirt 1 (adipose tissue-liver interaction). Avasimibe with other synthetic and nutritional Sirt 1 activators maintain brain function and reverse NAFLD associated with obesity and diabetes.

\section{Acknowledgement}

This work was supported by grants from Edith Cowan University, the McCusker Alzheimer's Research Foundation and the National Health and Medical Research Council.

\section{References}

1. Wells JC (2006) The evolution of human fatness and susceptibility to obesity: an ethological approach. Biol Rev Camb Philos Soc 81(12): 183-205.

2. Brantley PJ, Myers VH, Roy HJ (2005) Environmental and lifestyle influences on obesity. J La State Med Soc Spec No 1: S19-S22.

3. Martins IJ (2016) Anti-Aging Genes Improve Appetite Regulation and Reverse Cell Senescence and Apoptosis in Global Populations. AAR 5: $9-26$.

4. Ghosh HS (2008) The anti-aging metabolism potential of SIRT1. Curr Opin Investig Drugs 9(10): 1095-1102.

5. Pflugger PT, Herranz D, Velasco MS, Serrano M, Tshcop MN (2008) Sirt1 protects against high fat diets induced metabolic damage. Proc Natl Acad Sci USA 105(28):9793-9798.

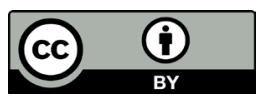

This work is licensed under Creative Commons Attribution 4.0 License

DOI: $10.19080 /$ NAPDD.2017.01.555561
6. Deng XO, Chen LL, Li NX (2007) The expression of SIRT1 in nonalcoholic fatty liver disease induced by high fat diets in rats. Liver Int 27(5): 708-715.

7. Martins IJ (2015) Unhealthy Nutrigenomic Diets Accelerate NAFLD and Adiposity in Global communities. J Mol Genet Med 9: 1-11.

8. Martins IJ (2016) Appetite Control with Relevance to Mitochondrial Biogenesis and Activation of Post- Prandial Lipid Metabolism in Obesity Linked Diabetes. Ann Obes Disord 1(3): 1012.

9. Martins IJ (2016) Drug Therapy for Obesity with Anti-Aging Genes Modification. Ann Obes Disord 1: 1001.

10. Martins IJ, Mortimer BC, Redgrave TG (1997) Effect of the ACAT inhibitor CL 277,082 on apolipoprotein B48 transport in mesenteric lymph and on plasma clearance of chylomicrons and remnants. Arterioscler Thromb Vasc Biol 17(1): 211-216.

11. Miyazaki A, Saki M, Sakamoto Y, Horiuchi S (2003) Acylcoenzyme A: cholesterol acyltransferase inhibitors for controlling hypercholesterolemia and atheroslcerosis. Curr Opin Investig Drugs 4(9): 1095-1099.

12. Puglielli L, Konopka G, Pack CE, Ingano LA, Berezowska LA, et al (2001) Acyl-conenzyme A cholesterol acyl transferase modulates the generation of the amyloid beta peptides. Nat Cell Biol 3(10): 905-912.

13. Puglielli L, Ellis BC, Ingano LA, Kovacs DM (2004) Role of acylcoenzyme a: cholesterol acyltransferase activity in the procesing of the amyloid precursor protein. J Mol Neurosci 24(1): 93-96,

14. Hutter PB, Huttunen HJ, Pugllielli L, Eckman CB, Kim DY, et al. (2004) The ACAT inhibitor CP-113,818 markedyl reduces amyloid pathology in a mouse model of Alzheimer's Disease. Neuron 44(2): 227-238.

15. Llaverías G, Laguna JC, Alegret M (2003) Pharmacology of the ACAT inhibitor avasimibe (CI-1011). Cardiovasc Drug Rev 21(1): 33-50.

16. Martins IJ, Wood KM, Fernandis AZ, Taddei, K, Martins RN (2013) AntiOxidative Acylcoa Cholesterol Acyltransferase Inhibitor Avasimibe Reduces the Impact of a High Cholesterol Diet on Brain Lipid Peroxidation in Mice. ADPD Florence.

17. Hubbard BP, Sinclair DA (2014) Small molecule SIRT1 activators for the treatment of aging and age-related diseases. Trends Pharmacol Sci 35(3): 146-154.

18. Martins IJ (2017) Inactivation of Anti-Aging Genes is Related to Defective Drug Metabolism in Diabetes. Int J Drug Disc 1: 3.

19. Martins IJ (2015) Diabetes and Organ Dysfunction in the Developing and Developed. GJMR 15(1): 1-8.

\section{Your next submission with Juniper Publishers} will reach you the below assets

- Quality Editorial service

- Swift Peer Review

- Reprints availability

- E-prints Service

- Manuscript Podcast for convenient understanding

- Global attainment for your research

- Manuscript accessibility in different formats ( Pdf, E-pub, Full Text, Audio)

- Unceasing customer service

Track the below URL for one-step submission

https://juniperpublishers.com/online-submission.php 